\title{
Different functions of PHF10 isoforms - subunits of the PBAF chromatin remodeling complex
}

\author{
A.A. Sheynov ${ }^{1}$, V.V. Tatarskiy ${ }^{1}$, A.M. Azieva ${ }^{1,2}$, S.G. Georgieva ${ }^{1}$, N.V. Soshnikova ${ }^{1}$ 図 \\ ${ }^{1}$ Institute of Gene Biology, RAS, Department of Eukariotic Transcription Factors, Moscow, Russia \\ 2 National Research Center "Kurchatov Institute", Moscow, Russia \\ 凶e-mail: so2615nat@gmail.com
}

Chromatin remodelling multiprotein complexes play an important role in regulation of gene expression in embryogenesis and in the adult organism. Mutations in the subunits of the complexes are often lethal or lead to developmental defects. Complexes consist of core subunits and a specific module. The core consists of ATPase and structure subunits, specific subunits of the module are necessary for chromatin binding. PHF10 (PHD finger protein 10) is a subunit of the PBAF (polybromo-associated BAF) chromatin remodelling complex subfamily. Conserved and highly regulated PHF10 is ubiquitously expressed in mammals as four different isoforms. The isoforms of PHF10 differ by domain structures and posttranslational modifications. All isoforms are highly regulated and included in the PBAF complex in a mutually exclusive manner. Two of the PHF10 isoforms (PHF10-P) are expressed at a high level in neuronal and myeloid progenitors and are necessary for cell proliferation. These isoforms contain PHD (plant homeodomain) fingers for nucleosome binding and recruit RNA polymerase II on the promoters of cell cycle genes. Two other isoforms (PHF10-S) instead of PHD have PDSM (phosphorylation-dependent sumoylation motif), the motif for SUMO1 conjugation. PHF10 is the most unstable subunit of the PBAF complex. Stability can alter the turnover rate of the subunits of the PBAF complex. All PHF10 isoforms are degraded by $\beta-T r C P$ ubiquitin ligase but PHF10-S isoforms contain a cluster of serins (X-cluster) for multiple phosphorylation by casein kinase I. This phosphorylation protects the $\beta$-TrCP degron from $\beta$-TrCP recognition and subsequently stabilizes the PHF10-S isoforms. Thus, the incorporation of PHF10 isoforms with different phosphorylation patterns and different stability into the PBAF complexes alters the functions of the entire PBAF complex and determines the range of genes undergoing remodelling.

Key words: chromatin remodeling; PBAF complex; PHF10 isoforms.

For citation: Sheynov A.A., Tatarskiy V.V., Azieva A.M., Georgieva S.G., Soshnikova N.V. Different functions of PHF10 isoforms - subunits of the PBAF chromatin remodeling complex. Vavilovskii Zhurnal Genetiki i Selektsii=Vavilov Journal of Genetics and Breeding. 2019;23(2):184-189. DOI 10.18699/VJ19.480

\section{Функции изоформ РНF10 - субъединицы PBAF комплекса, ремоделирующего хроматин}

\author{
А.А. Шейнов ${ }^{1}$, В.В. Татарский ${ }^{1}$, А.М. Азиева ${ }^{1,2}$, С.Г. Георгиева ${ }^{1}$, Н.В. Сошникова ${ }^{1} \otimes$ \\ ${ }^{1}$ Институт биологии гена Российской академии наук, Москва, Россия \\ ${ }^{2}$ Национальный исследовательский центр «Курчатовский институт», Москва, Россия \\ هe-mail: so2615nat@gmail.com
}

Комплексы, ремоделирующие хроматин, играют важную роль в экспрессии генов при эмбриональном развитии и во взрослом организме. Мутации субъединиц этого комплекса часто летальны или приводят к дефектам развития. Один из основных комплексов эукариот, изменяющих структуру хроматина, - комплекс РBAF, входящий в семейство SWI/SNF комплексов. Комплекс PBAF состоит из коровых субъединиц (Brg1, BAF155/BAF170, BAF47 и др.) и субъединиц специфического модуля (PHF10, BAF200, BAF180 и BRD7). Коровые субъединицы - это структурные субъединицы и АТФаза, специфические субъединицы - субъединицы, необходимые для связывания хроматина. Субъединичный состав комплекса не является постоянным. В процессе развития и дифференцировки клеток организма субъединицы комплекса заменяются гомологичными, что обуславливает специфичность работы комплекса на различных генах. Белок PHF10 - субъединица модуля PBAF комплекса, он играет важную роль в регуляции генов млекопитающих. В клетках и тканях человека и мыши PHF10 представлен четырьмя изоформами. Изоформы PHF10 имеют разную доменную структуру N- и C-концов, что определяет их свойства - различную клеточную локализацию, стабильность и модификационные паттерны. Две изоформы PHF10 (PHF10-P) экспрессируются на высоком уровне в нейрональных и миелоидных предшественниках и необходимы для пролиферации клеток. Эти изоформы содержат домены типа «PHD-пальцев», необходимые для связывания нуклеосом, и рекрутируют РНК-полимеразу II на промоторы генов клеточного цикла. Две другие изоформы (PHF10-S) вместо PHD доменов на C-конце имеют мотив PDSM для конъюгации SUMO1. Белок PHF10 представляет собой наиболее нестабильную субъединицу комплекса PBAF. Стабильность изоформ может регулировать скорость замены субъединиц в PBAF комплексе. Bсе PHF10 изоформы деградируют посредством убиквитинирования, 


\begin{abstract}
осуществляемого B-TrCP убиквитин-лигазой, и дальнейшего расщепления 26-S протеасомой. Изоформы PHF10 содержат кластер серинов (Х-кластер), подвергающийся интенсивному фосфорилированию казеин-киназой. Это фосфорилирование защищает B-TrCP дегрон от узнавания B-TrCP убиквитин-лигазой и последующей деградации, что приводит к большей стабильности PHF10-S форм по сравнению с PHF10-P формами. Таким образом, включение в PBAF изоформ PHF, обладающих различными паттернами фосфорилирования и различной стабильностью, влияет на функции целого PBAF комплекса и определяет спектр ремоделируемых генов. Ключевые слова: ремоделирование хроматина; PBAF комплекс; изоформы PHF10.
\end{abstract}

\section{Introduction}

One of the most widely represented families of chromatinremodelling complexes is the family of ATP-dependent complexes SWI/SNF (SWItch/Sucrose Non-Fermentable). These complexes use the energy of ATP hydrolysis to locally disrupt or alter the association of histones with DNA (Vignali et al., 2000) and play crucial role in chromatin assembly. This family is highly conserved in eukaryotes. At the same time, in the process of evolution, it acquires an increasing complexity in the structure, following the demand for increasing complexity of chromatin organization and chromatin regulation in multicellular organisms. For example, in yeast (Saccharomyces cerevisiae) chromatin does not contain methylated DNA or linker histones and the complexes perform the function of a transcriptional activator only. In the transition to multicellular organisms, the complexes acquire new components and a greater variation in composition and additional functions. Higher eukaryotes exhibit an increased genome size and a more complex genomic organization.

The complexes act as transcriptional activators and repressors and the large combinatorial diversity, which is associated with the incorporation of homologous subunits and different isoforms in the complexes, provides assemblies that are tissuespecific or specific to a certain developmental stage (Ho, Crabtree, 2010). In mammals, SWI/SNF is represented by two subfamilies of complexes - BAF (BRG-/BRM-associated factor) and PBAF that differ by subunit composition (Tang et al., 2010). Each complex contains subunits that form the core part and several specific subunits that form the module relevant to a particular type of complex. The core part of SWI/SNF complex consists of ATPase which is encoded by homologous Brgl or Brm genes, and several structural subunits - BAF155/
BAF170, BAF47, BAF60, actin. Specific subunits (BAF200, BAF180, BRD7, PHF10 of PBAF and BAF250a/b of BAF) are responsible for interaction with chromatin. Almost all subunits of the complex can be replaced by paralogs. In particular, this leads to greater variability of subunit composition and, subsequently, to a wider range of functions of this complex. This also determines the pattern of the expression of target genes and specifies the regulation of nucleosome remodelling. Post-translational modifications of SWI/SNF complex subunits impact on the regulation of its functions even more (Simone, 2006).

The chromatin-remodelling complex of the PBAF family plays an essential role in the regulation of gene expression during embryogenesis. Mutations in the subunits of this complex are often lethal or lead to developmental defects (Hodges et al., 2016). Also, many mutations were characterized as secondary mutations during oncogenesis, leading to the advanced course of disease (Masliah-Planchon et al., 2015). One of the most modificated and regulated subunits is the protein PHF10, characterized by our group (Brechalov et al., 2014; Tatarskiy et al., 2017).

\section{Structural domains of PHF10 are evolutionary conserved}

The two main structural domains of PHF10, SAY (supporter of activation of yellow) and PHD, are evolutionarily conserved and are represented in all multicellular organisms. The length of the $\mathrm{N}$ - and $\mathrm{C}$ - terminal unstructured regions may vary (Fig. 1) (Vorobyeva et al., 2009).

The most thoroughly studied homologue of PHF10 in Drosophila is the protein SAYP (supporter of activation of yellow protein). The homozygous SAYP knockout in Drosophila,

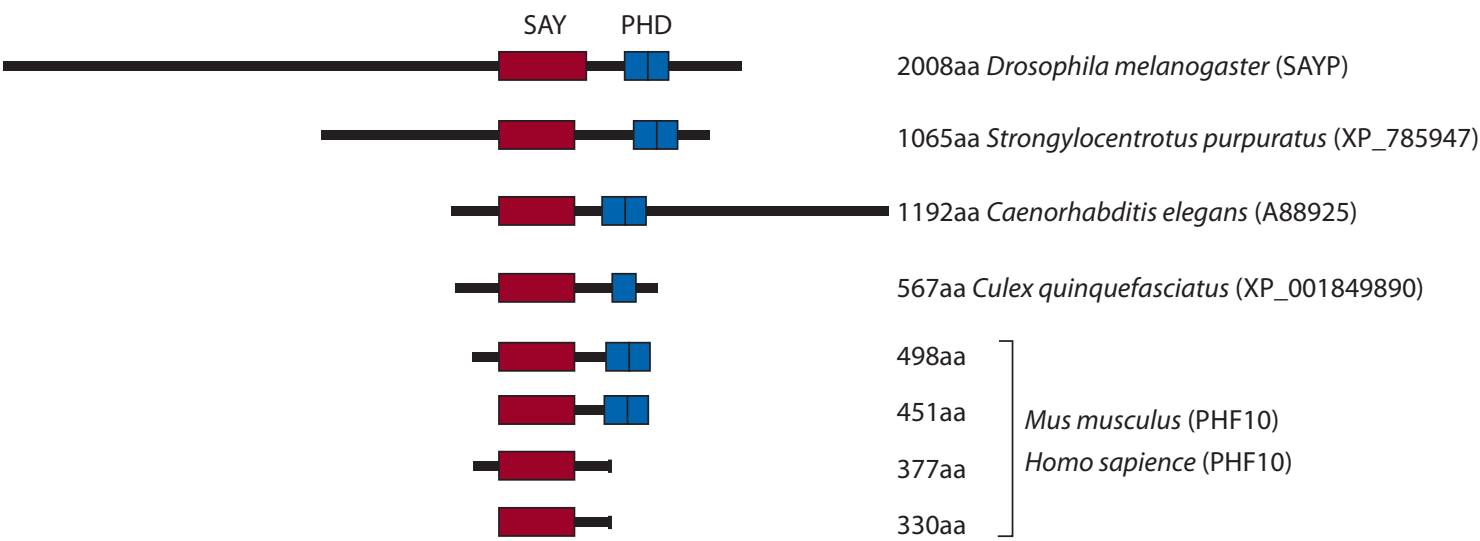

Fig. 1. PHF10 isoforms and their homologues in different species.

The total lengths of the proteins are indicated Drosophila melanogaster, SAYP; Strongylocentrotus purpuratus, XP_785947 locus; Caenorhabditis elegans, A88925 locus; Culex quinquefasciatus, XP_001849890 locus; Mus musculus, PHF10; Homo sapiens, PHF10. The total lengths of the proteins are indicated. SAY domain is depicted as a red box. PHD finger domain is depicted as a blue box. Adopted from (Vorobyeva et al., 2009). 


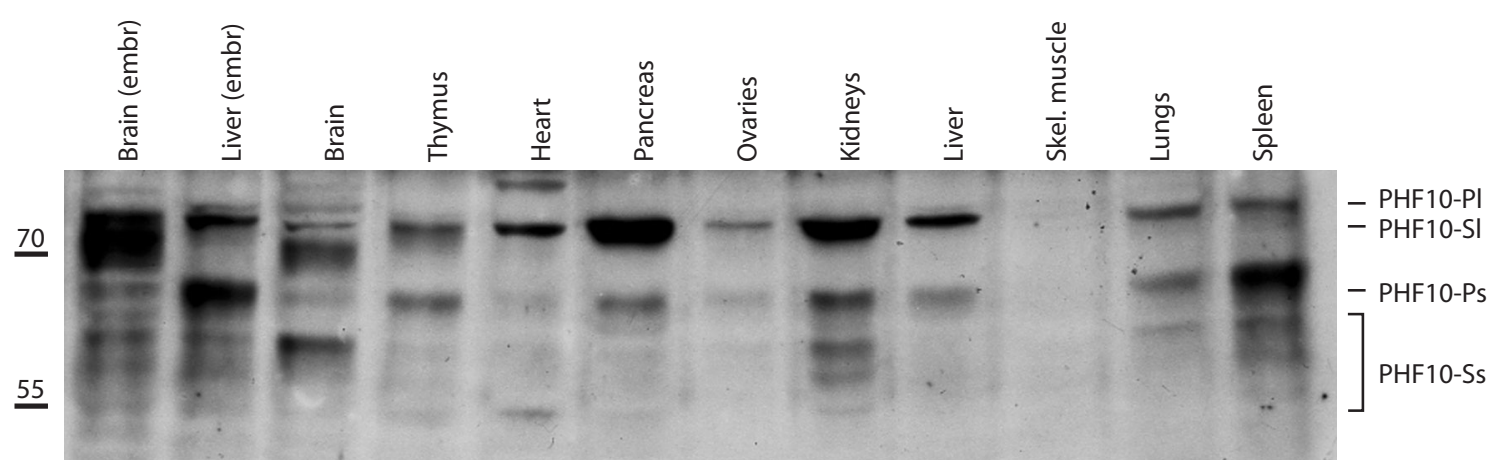

Fig. 2. Equal amount of protein $(40 \mu \mathrm{g})$ was loaded on each lane.

Each lane indicates different PHF10 isoforms contained in various tissues. Detection of PHF10 in extracts from corresponding tissue by western blotting with affinity purified anti-PHF10 antibodies. Set of protein bands in a molecular weight range of about $60-80 \mathrm{kDa}$ corresponds to different isoforms. The presence of multiple (more than four) bands and the difference between the predicted and the real molecular weight is due to the presence of post-translational modifications.

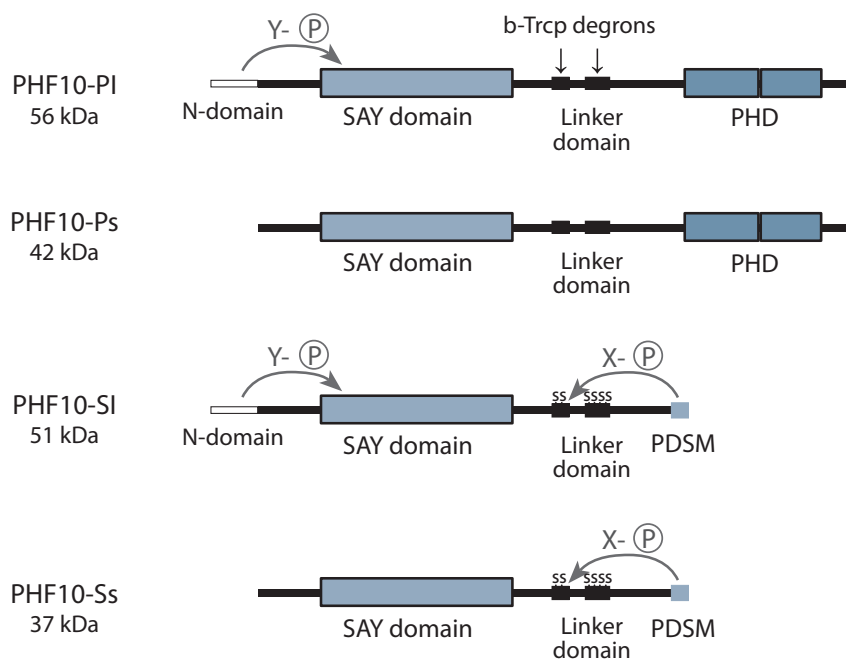

Fig. 3. Domain structure and phosphorylation patterns of PHF10 isoforms.

PHF10-P isoform contains two PHD domains at the C-terminus. PHF10-S isoform contains PDSM. Also both isoforms differ in N-terminal parts by the presence or absence of 46 amino acids: "I" - long and "s" - short. X- and Y-phosphorylation clusters are depicted. $\beta$-TrCP degrons depicted as thick black lines. Adopted from (Tatarskiy et al., 2017).

as well as the homozygous PHF10 knockout in a mouse is embryonic lethal (Krasteva et al., 2017). That suggests an important role of this protein in the expression of developmental genes. In the adult Drosophila, SAYP is mainly expressed in female ovaries (Vorobyeva et al., 2009), while PHF10 is expressed in almost all tissues of the mammalian organism (Brechalov et al., 2016), (Tissue expression of PHF10..., 2018) (Fig. 2).

Unlike Drosophila, where SAYP is represented by a polypeptides of 2006-2012 amino acids that have similar domain structure (FlyBase n.d., 2019), four isoforms of PHF10 that have a different domain structure are expressed in mammals. These isoforms are evolutionarily highly conserved in different mammalian species (Brechalov et al., 2014), which supports the existence of important functions of each isoform (Fig. 3).

\section{Domain organisation of PHF10 isoforms}

All four isoforms of PHF10 are the products of the same gene, and are formed as a result of alternative splicing of transcripts and differ in $\mathrm{N}$ - and $\mathrm{C}$-terminal domains (see Fig. 3). The first isoform that was described contains two PHD domains at the C-terminus and was designated by us as the isoform PHF10-P (containing the PHD domain). Another isoform lacks a PHD domain, instead of it six C-terminal amino acids form PDSM (phosphorylation-dependent sumoylation motif) that regulates phosphorylation-dependent sumoylation. We designated this isoform as PHF10-S (see Fig. 3). Also, PHF10-P and PHF10-S isoforms may differ in N-terminal parts by the presence or absence of 46 amino acids: "l" - long and "s" - short (see Fig. 3). Molecular weight is 56, 42, 51, $37 \mathrm{kDa}$ for isoforms $\mathrm{PHF} \mathrm{PL} / \mathrm{Ps} / \mathrm{SL} / \mathrm{Ss}$ respectively.

All PHF10 isoforms contain an evolutionary conserved SAY domain, which is responsible for the incorporation of protein in the PBAF complex (see Fig. 3). In mammals, the SAY domain seems to be uniquely represented only in the structure of the PHF10 isoforms, although in a number of works some homology of the SAY domain with the N-terminal domain of BAF47 and Kruppel-like BAF45b/c/d subunits of BAF complexes was found (Lessard et al., 2007; Allen et al., 2015).

The PHF10-P and PHF10-S isoforms are included in the PBAF complex in a mutually exclusive manner. In other words, there are PBAF complexes that contain PHF10-P isoforms, and PBAF complexes that contain PHF10-S isoforms (Brechalov et al., 2014). The incorporation of different isoforms into the complex does not lead to a change in the subunit composition of the complex (Brechalov et al., 2014). However, different isoforms may interact with different activators or transcriptional coactivator complexes, leading to modulation of mechanisms of functioning of the PBAF complexes containing different PHF10 isoforms.

The PHF10-P isoforms contain two PHD zinc finger domains. It has been shown that these domains can bind the N-terminal "tails" of histones, especially trimethylated histone H3 lysine 4 (Hyun et al., 2017). The specific ligand has not yet been found for PHD domains of the PHF10-P isoforms, but it is likely that the incorporation of PHF10-P isoform in 
the complex may determine the binding of the PBAF complex to specifically modified nucleosomes.

PHF10-S isoforms do not contain PHD domains that recognise nucleosomes. However, they can covalently attach a small ubiquitin-related modifier protein, SUMO1, to the C-terminus (Fig. 4) (Brechalov et al., 2014). The role of the sumoylation of PHF10-S isoforms is not yet clear, but it is known that protein sumoylation can affect their turnover, localisation and determine other proteins interacting with them (Seeler, Dejean, 2017). Thus, the incorporation of various isoforms in the PBAF complex can significantly change the functions of the entire complex, influence the range of protein binding partners, and position the PBAF complex on chromatin. Therefore, this determines the patterns of genes that the PBAF complex remodels (Brechalov et al., 2014).

\section{Functions of PHF10 isoforms}

It has been shown that PBAF complexes that contain PHF10 isoforms with PHD domains have a positive effect on the transcription of genes that are involved in cell proliferation, comparing to the PHF10-S isoform. The percentage of proliferation genes that changed their expression relative to the total number of differentially expressed genes during overexpression of PHF10-Pl and PHF10-Sl isoforms in HEK293 cells compared to control, non-transfected cells, was $9.23 \%$ and $4.28 \%$ respectively. These changes in gene expression led to an increase in the number of cell divisions per unit of time (from 3.4 to 4.3 in 24 hours and from 8.8 to 11.4 in 48 hours) in cells overexpressing the PHF10-Pl isoform, compared to control. The number of divisions in the cells expressing the PHF10-Sl isoform was comparable to the control (Brechalov et al., 2014).

Using chromatin immunoprecipitation, we showed that the PHF10-Pl and the PHF10-Sl isoforms are present in the PBAF complexes on the promoters of genes involved in cell proliferation ZMIZ1 and NOV. However, only PHF10-P overexpression resulted in an increased level of RNA polymerase II on the promoter, which correlated with an increase in level of ZMIZ1 and NOV mRNA (Brechalov et al., 2014). That is consistent with a model in which PBAF complexes containing the PHF10-Pl isoform, regulate gene expression differently than PBAF complexes containing the PHF10-Sl isoform.

In the study of mouse brain development, J. Lessard (2007) showed that PHF10-Pl is highly expressed during the process of embryonic brain development, with increased expression in proliferating neurons. During the transition from proliferating progenitor cells to postmitotic neurons, expression of the PHF10-Pl isoforms is stopped along with the increase in expression of short PDSM-containing isoforms PHF10-Ss (Azieva et al., 2018).

PBAF complexes that contain the PHF10-Pl isoform were localised on the promoters of the SHH-Olig and Notch signalling genes, responsible for the development of the mouse brain (Lessard et al., 2007).

Also, the important role of PHF10 isoforms in the development of blood cells was shown on mouse models. In the hematopoietic stem cells, the PHF10-Pl isoforms are expressed at a high level. High expression of PHF10-Pl isoforms maintains a pool of stem cells. Conditional knockout of Phflo in the hematopoietic tissue of an adult mouse leads to depletion

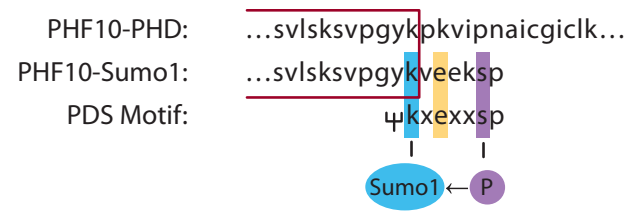

Fig. 4. The consensus sequence for phosphorylation-dependent SUMO modification (PDSM) at the $\mathrm{C}$ terminus of PHF10-SI/Ss isoforms and scheme of amino acids sumoylation.

Red box indicates the common part of PHF10-P and PHF10-S isoforms. Adopted from (Brechalov et al., 2014).

of the pool of blood stem cells and reduces the number of myeloid progenitors, mature macrophages, monocytes and granulocytes in bone tissue (Krasteva et al., 2017). We have also shown that during myeloid differentiation, the PHF10-P1 isoform in the PBAF complex is replaced by the PHF10-Ss isoform, which affects the patterns of actively transcribed genes.

\section{Post-translational modifications of PHF10 isoforms}

According to the phosphosite.org database (Phosphosite Knowledgebase n.d., 2018), the subunits of the PBAF complex are intensively phosphorylated. A particularly large number of sites (more than 20 per protein) are located in the BRG1, BAF155, BAF200, BAF180, BRD7, and PHF10 subunits. Phosphorylation by various kinases provides a complex regulation of the functions of the PBAF complex and sensitivity to various signalling pathways (Simone, 2006). Phosphorylation of subunits alters the charge of the complex and allows it to bind to various proteins, thus providing specificity in the reprogramming of gene expression (Cui et al., 2016).

Different isoforms of PHF10 have different phosphorylation patterns that are dependent on their domain structure (see Fig. 3) (Tatarskiy et al., 2017). The additional N-terminal domain of 47 amino acids that exists in the long PHF10-P1/ $\mathrm{Sl}$ isoforms contributes to the presence of the phosphorylation pattern, which we designated as Y (see Fig. 3). The absence of PHD domains inherent to the isoforms of PHF10-S1/Ss contributes to the phosphorylation of a number of serines in the linker domain. We designated this cluster as X-phosphorylation (see Fig. 3). Also, PHF10-Sl and PHF10-Ss have a six amino acids PDSM motif at the C-terminus. We have determined that the lysine can covalently bind the SUMO1 modifying protein. Moreover, sumoylation occurs more intensively if the subsequent serine is phosphorylated in this motif (see Fig. 4) (Brechalov et al., 2014).

Another function of phosphorylation is the regulation of protein stability. Due to the different stability of the subunits, the additional regulation of the functions of the complex is provided by the replacement of a subunit via degradation of the unnecessary one (Sears et al., 2000; Liu et al., 2002; Hafumi et al., 2011).

PHF10 is one of the most phosphorylated and unstable subunits of the PBAF complex (Brechalov et al., 2014, 2016; Tatarskiy et al., 2017; Azieva et al., 2018). Our studies revealed that PHF10 isoforms contain the non-canonical $\beta$-TrCP ubiquitin ligase recognition motif and are degraded by $\beta-\operatorname{TrCP}$ 


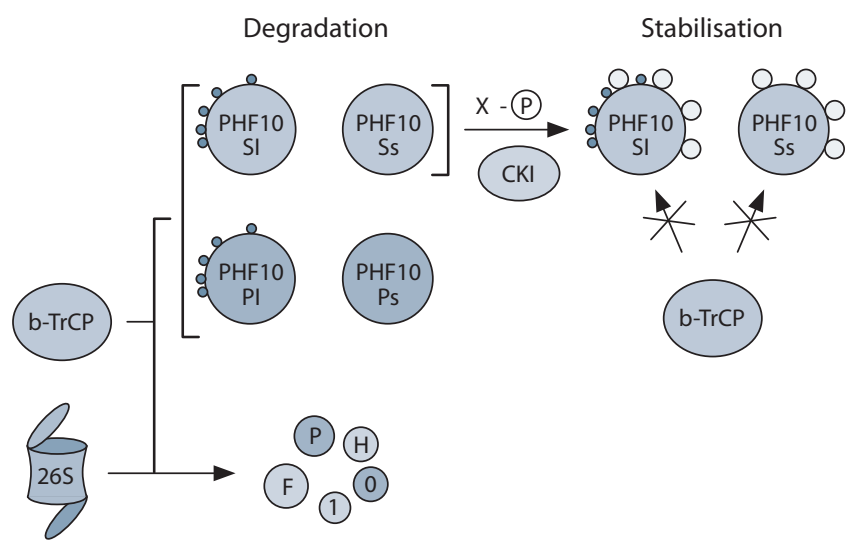

Fig. 5. Diagram of PHF10 degradation.

PHF10 isoforms contain the non-canonical $\beta$-TrCP ubiquitin ligase recognition motif and are degraded by $\beta-\operatorname{TrCP}$ in a phospho-dependent manner through $26 \mathrm{~S}$ proteasome. Phosphorylation by CKI (casein kinase I) of serines in the $\mathrm{X}$-cluster in the linker domain of the PHF10-SI/Ss isoforms impairs interaction of isoforms with $\beta$-TrCP and opposes their degradation. Large light circles X-cluster phosphorylation; small dark - Y-cluster phosphorylation. Adopted from (Tatarskiy et al., 2017).

in a phospho-dependent manner. The non-canonical recognition motif for ligase is localised in the linker domain and is represented in all isoforms (Tatarskiy et al., 2017).

The function of phosphorylation of serines organized in the $\mathrm{X}$-cluster in the linker domain of the isoforms PHF10-S1/Ss was thoroughly studied by our group (Tatarskiy et al., 2017). $\mathrm{X}$-cluster serines are phosphorylated by casein kinase 1 . $\mathrm{X}$-cluster contains positively charged amino acids $-\beta$-TrCP degron. Normally $\beta$-TrCP recognises this degron and contributes to the degradation of PHF10 isoforms. The X-cluster phosphorylation block the positive charges and opposes the interaction $\beta$-TrCP ubiquitin ligase with its degron (Tatarskiy et al., 2017). Thus, phosphorylation of X-cluster serines leads to a significant stabilization of the PHF10-S1 and PHF10-Ss isoforms, compared to the stability of PHF10-Pl and PHF10-Ps isoforms (Fig. 5) (Tatarskiy et al., 2017).

\section{Conclusions}

Thus, the isoforms of PHF10, being part of the PBAF complex, are highly regulated through post-translational modifications providing a broad variety of their functions through the ability to accept messages of signalling pathways. Also, the incorporation into the PBAF complexes of PHF10 isoforms with different phosphorylation patterns and different stability alters the functions of the entire PBAF complex and determines the range of genes undergoing remodelling.

\section{References}

Allen M.D., Freund S.M.V., Zinzalla G., Bycroft M. the SWI/SNF subunit INI1 contains an N-terminal winged helix DNA binding domain that is a target for mutations in schwannomatosis. Structure. 2015;23(7):1344-1349. DOI 10.1016/j.str.2015.04.021.

Azieva A.M., Sheinov A.A., Galkin F.A., Georgieva S.G., Soshnikova N.V. Stability of chromatin remodeling complex subunits is determined by their phosphorylation status. Dokl. Biochem. Biophys. 2018;479(1):66-68. DOI 10.1134/S1607672918020035.
Brechalov A.V., Georgieva S.G., Soshnikova N.V. Mammalian cells contain two functionally distinct PBAF complexes incorporating different isoforms of PHF10 signature subunit. Cell Cycle. 2014;13(12):1970-1979. DOI 10.4161/cc.28922.

Brechalov A.V., Valieva M.E., Georgieva S.G., Soshnikova N.V. PHF10 isoforms are phosphorylated in the PBAF mammalian chromatin remodeling complex. Mol. Biol. 2016;50(2):278-283. DOI 10.1134/ S0026893316010039.

Cui H., Schlesinger J., Schoenhals S., Tönjes M., Dunkel I., Meierhofer D., Cano E., Schulz K., Berger M.F., Haack T., AbdelilahSeyfried S., Bulyk M. L., Sauer S., Sperling S.R. Phosphorylation of the chromatin remodeling factor DPF3a induces cardiac hypertrophy through releasing HEY repressors from DNA. Nucleic Acids Res. 2016;44(6):2538-2553. DOI 10.1093/nar/gkv1244.

FlyBase. n.d. "FlyBase Gene Report: Dmelle(y)3." Accessed January 18, 2019. http://flybase.org/reports/FBgn0087008.

Hafumi N., Hashimoto K., Panchenko A.R. Phosphorylation in proteinprotein binding: effect on stability and function. Structure. 2011; 19(12):1807-1815. DOI 10.1016/j.str.2011.09.021.

Ho L., Crabtree G.R. Chromatin remodelling during development. Nature. 2010;463(7280):474-484. DOI 10.1038/nature08911.

Hodges C., Kirkland J.G., Crabtree G.R. The many roles of BAF $(\mathrm{mSWI} / \mathrm{SNF}$ ) and PBAF complexes in cancer. Cold Spring Harb. Perspect. Med. 2016;6(8):a026930. DOI 10.1101/cshperspect.a026930.

Hyun K., Jeon J., Park K., Kim J. Writing, erasing and reading histone lysine methylations. Exp. Mol. Med. 2017;49(4): e324. DOI 10.1038/emm.2017.11.

Krasteva V., Crabtree G.R., Lessard J.A. The BAF45a/PHF10 subunit of SWI/SNF-like chromatin remodeling complexes is essential for hematopoietic stem cell maintenance. Exp. Hematol. 2017;48:5871.e15. DOI 10.1038/emm.2017.11.

Lessard J., Wu J.I., Ranish J.A.,Wan M.,Winslow M.M., Staahl B.T., Wu H., Aebersold R., Graef I.A., Crabtree G.R. An essential switch in subunit composition of a chromatin remodeling complex during neural development. Neuron. 2007;55(2):201-215. DOI 10.1016/j. neuron.2007.06.019.

Liu C., Li Y., Semenov M., Han C., Baeg G.H., Tan Y., Zhang Z., Lin X., He X. Control of $\beta$-catenin phosphorylation/degradation by a dual-kinase mechanism. Cell. 2002;108(6):837-847. DOI 10.1016/ s0092-8674(02)00685-2.

Masliah-Planchon J., Bièche I., Guinebretière J.M., Bourdeaut F., Delattre O. SWI/SNF chromatin remodeling and human malignancies. Annu. Rev. Pathol. 2015;10:145-171. DOI 10.1146/annurevpathol-012414-040445.

Phosphosite Knowledgebase. n.d. Accessed October 22, 2018. http:// phosphosite.org.

Sears R., Nuckolls F., Haura E., Taya Y., Tamaid K., Nevins J.R. Multiple Ras-dependent phosphorylation pathways regulate myc protein stability. Genes Dev. 2000;14(19):2501-2514. https://www.ncbi. nlm.nih.gov/pubmed/11018017.

Seeler J.S., Dejean A. SUMO and the robustness of cancer. Nat. Rev. Cancer. 2017;17(3):184-197. DOI 10.1038/nrc.2016.143.

Simone C. SWI/SNF: the crossroads where extracellular signaling pathways meet chromatin. J. Cell. Physiol. 2006;207(2):309-314. DOI $10.1002 /$ jep. 20514.

Tang L., Nogales E., Ciferri C. Structure and function of SWI/SNF chromatin remodeling complexes and mechanistic implications for transcription. Prog. Biophys. Mol. Biol. 2010;102(2-3):122-128.

Tatarskiy V.V., Simonov Y.P., Shcherbinin D.S., Brechalov A.V., Georgieva S.G., Soshnikova N.V. Stability of the PHF10 subunit of PBAF signature module is regulated by phosphorylation: role of $\beta$-TrCP. Sci. Rep. 2017;7(1):5645. DOI 10.1038/s41598-017-05944-3. 
Tissue expression of PHF10 - Summary - The Human Protein Atlas. n.d. Accessed October 22,2018.

Vignali M.A., Hassan H., Neely K.E., Workman J.L. ATP-dependent chromatin-remodeling complexes. Mol. Cell. Biol. 2000;20(6):18991910. https://www.ncbi.nlm.nih.gov/pubmed/10688638.
Vorobyeva N.E., Soshnikova N.V., Kuzmina J.L., Kopantseva M.R., Nikolenko J.V., Nabirochkina E.N., Georgieva S.G., Shidlovskii Y.V. The novel regulator of metazoan development SAYP organizes a nuclear coactivator supercomplex. Cell Cycle. 2009;8(14):2152-2156. DOI 10.4161/cc.8.14.9115.

https://www.proteinatlas.org/ENSG00000130024-PHF10/tissue.

\section{ORCID ID}

A.A. Sheynov orcid.org/0000-0002-3302-2797

V.V. Tatarskiy orcid.org/0000-0002-9080-5683

A.M. Azieva orcid.org/0000-0003-2222-6302

S.G. Georgieva orcid.org/0000-0003-3665-0390

N.V. Soshnikova orcid.org/0000-0001-9260-3068

Acknowledgements. This study was supported by the Russian Science Foundation (grant No. 18-14-00303 to S.N.). The experiments were carried out using infrastructure of Center for collective use of the Institute of Gene Biology, Russian Academy of Science: "Biology of the living cell and drug biomedical nanotransporters".

Conflict of interest. The authors declare no conflict of interest.

Received November 22, 2018. Revised January 18, 2019. Accepted January 24, 2019. 